Submarine Miners : The Severn Division : Surgeon-Captain

A. Rees to be Surgeon-Major.

Rifle: 2nd Volunteer Battalion the King's (Liverpool Regiment): Surgeon-Captain N. F. Roberts to be Surgeon-Major. 4th Tolunteer Battalion the Devonshire Regiment: SurgeonCaptain F. B. Manning resigns his commission. 1st Volunteer Battalion the Essex Regiment: Surgeon-Captain St. C. B. Shadwell to be Surgeon-Major. 14th Middlesex (Inns of Court): Surgeon-Captain H. M. Ramsay to be SurgeonMajor; Surgeon-Lieutenant F. C. Wallis to be SurgeonCaptain.

Royal Aryy Medical Corps (Volunteers).

The London Companies: Captain H. D. Buss resigns his commission.

VOLUNTEER INFANTRY: BRIGADE BEARER COMPANY.

South Yorkshire: Surgeon-Captain W. K. Clayton, from 1st Volunteer Battalion the King's Own (Yorkshlle Light Infantry), to be Surgeon-Captain, and to command under paragraph 55A Volunteer Regulations.

Surgeon-Lieutenant F. J. Sidler, from the 2nd Volunteer Battalion the York and Lancaster Regiment, to be SurgeonLieutenant.

VOLUNTEER OFFICERS' DECORATION.

The Volunteer Officers' Decoration has been conferred upon Lieutenant-Colonel Francis Lawrance Stephenson of the Woolwich Companies, Rớyal Army Medical Corps (Volunteers).

\section{OUTSPOKEN CRITICISM.}

The Arohives de Médeoine Navale, an official journal pubblished "by order of the Minister of Marine," contains in its June issue a short article in which Dr. Astius Cistellan, who is a naval medical officer of the first class, finds fault very unreservedly $w$ th the convalescent depôt for French colonial troops which has been established on the island of Porquerolles. This sanatorium, says the outspoken critic, having been in existence since January, 1898, ought by this time to be organised on a solid ba-is, but such is far from being the case. In the first place the site that has been pitched on is entirely unsuitable for the purpose. "In this marvellous island," continues Dr, Castellan, "there are several places where the depôt could have been established under far better conditions, amidst the health-bestowing emanations from the pine groves, but instead of that it stands quite close to the village, on a bare hillock destitute of verdure and entirely unshaded. The rooms, professing to accommodate 16 convalescent men in each, are overcrowded; the kitchen is only a kitchen in name, being filthy, full of cobwebs, and shockingly furnished; the latrine, unprovided with water-supply and very imperfectly cleansed, is placed to windward of the cantonment; there are no drains properly so-called, only a few shallow trenches where putrescible matter lies stagnant and rotting in the sun; the pharmacy and dressing-room is so small and dark that it is impossible to examine or dress a patient in it ; finally, in the immediate neighbourhood there is a village of some 250 inhabitants in which there are no fewer than seven liquor shops, some of them being suspected of harbouring improper characters.

The Overcrowided Transports.

It is not easy to exaggerate the grave importance of the allegations that have been made regarding the disgracefn state of the transports conveying the colonial troops from South Africa to their various destinations. The affair has very naturally and properly given rise to a good deal of feeling in the colonies. A Royal Commission has been appointed, and if the charges that have been advanced are substantiated we can only trust that the blame will be brought home to those concerned.

\section{The Welsh Hospital.}

A hand-ome brais tablet to the memory of six members of the staff of the Welsh Hospital who died durirg the recent war in South Africa was unveiled in St. David's Cathedral on August 14th by Lord Penrhyn. The names on the tablet are those of Professor A. W. Hughes, Professor ' $T$. Jones, Dr. H. Davies, 'T. R. Eames (dresser), Marion Lloyd (matron', and Florence L. Sage (nursing sister).

Royal College of Physicians of London.In the list of gentlemen allmitted on July 31st as Members of the College, publinhed in THE LANCET of August 9th, p. 396, the fullowing name was accidentally omitted:Andrew Elliot, M.A., M. D. Edin.

\section{Clotespondence.}

\author{
"Audi alteram partem." \\ THE DUTIES OF A MEDICAL MAN AND \\ THE LAW OF LIBEL.
}

To the Editors of THE LA N $\mathbf{T} \mathbf{E}$.

SIRS,-I have read with interest the letter of Dr. ShawMackenzie on the above but must confess that I think he has taken too gloomy a view in respect of the dangers run by medical men in the particular instance he quotes. He states in his letter that publication of a wife's disease to the husband would undoubtedly be sufficient to cause an action to lie against the medical attendant and suggests that an alteration in the law of libel is desirable. It is quite clear from the recorded cases that such a statement made bon $\hat{a}$ fide by a medical man would be held to be "privileged." Only lately in a case held at Leeds Assizes the learned judge extended the "privilege" in this respect not only to the communication made to the husband but also to the employer and also to the housekeeper in whose employment and under whose domestic care the wife was. Further than this "privilege" can hardly be expected to extend.

I am, Sirs, yours faithfully,

August 18th, 1902. General Secretary, Medical Defence Union.

\section{PATENT FOODS.}

To the Editors of THE LANCET.

SIRS, - I have read with much interest the valuable and exhaustive address by Dr. R. Hutchison on Patent Foods published in THe LANCET of July 5th (p. 1). There is one point, however, in respect of somatore that is worthy of note. Dr. Hutchison, after stating that somatose is "a good albumose food and a very rich one, containing 80 per cent. of digested proteid," goes on to say that "if it is given in anything like large quantities it is apt to produce diarrhoea and for that reason its use is seriously restricted in practice."

I do not think that this is a universal experience. I have used somatose more or less since 1897 and I bave scarcely ever foun that it has produced any diarrhoea. and $I$ arn anxious to say a good word for it. I think that it is more than probable that the mode of administration has a great deal to do with the results obtained. It is imperative, in the exhibition of somatose, that it should be administered at first in small doses, but frequently, three, four, or more times in 24 hours, gradually in creasing every few days until the full dose is cbtained. Another thing is also essential-that is, that it should be in complete solution before being swallowed. The cnly cases in which $I$ have seen slight diarrhoea in the use of :omatose are those in which this precaution has been neglected and the substance has been lumpy. I have given somatose in adults in quantities of from three to six drachms per day, and to children from 45 to 90 grains, without any unpleasant effects and with the best results.

In July, 1899, I wrote a small brochure on somatose which appeared in the Scalpel during that month. On reference to it I find that I have made no mention of diarrhcea, but, as there stated, it has done me yeoman's service, the great increase of body-weight being astonishing, as much as from two to three pounds having been put on in seven days. Dr. J. L. Landau in Die Heilkunde, September, 1898, quotes a series of cases in which he exhibited somatose and he states: "The manner of preparing this solution is deserving of very special consideration. Into a wineglass containing a tablespoonful of water or other medium the desired quantity of somatose is poured and the resulting paste stirred for a few minutes until a complete solution is obtainer." He further states that when given to children in the followiug manner-one gramme for the fir:t three days and then increased up to three grammes in eight days-no diarrhcea has occurred. He has also used it in ga-tro-intestinal cases, where there was persistent lo-s of apt etite, diarrhoea, and vomiting, from one to five grammes of somatose being given at first, gradually increased to eight grammes. As a result, by the seccnd day the stools bad 